\title{
The Influence of Financial Literacy on Interest in Investing for the Academic Community of Akademi Keuangan \& Bisnis Indonesia Internasional (AKBII), Bandung, Indonesia
}

\author{
Hamka $^{1,2^{*}}$, Helly Siti Halimah ${ }^{1,2^{*}}$, Mohamad Jupri ${ }^{1,2}$, Ruly Budiono ${ }^{1 *}$, Abdul Malek A Tambi ${ }^{3}$ \\ ${ }^{1}$ Akademi Keuangan \& Bisnis Indonesia Internasional (AKBII), Bandung, Indonesia \\ ${ }^{2}$ Post Graduate at Faculty of Economics and Management Science, Universiti Sultan Zainal Abidin, Terengganu, Malaysia, \\ ${ }^{3}$ Faculty of Economic and Management Science, Universiti Sultan Zainal Abidin, Terengganu, Malaysia.
}

*Corresponding author e-mail address: hamka1509@gmail.com; hellyunisza@gmail.com; ruly@unpad.ac.id

\begin{abstract}
This paper aims to analyze the effect of financial literacy on investment interests among academicians. The study was conducted on all four aspects of financial literacy, namely general knowledge of personal finance, savings and loans, insurance, and investment partially and simultaneously on investment decisions from lecturers, employees, and students at the Indonesian International Finance and Business Academy in Bandung. The subjects in this study were lecturers, employees, and active students majoring in management and accounting at the Indonesian International Finance and Business Academy in Bandung with a total number of 240 questionnaire respondents. The results of the analysis show that financial literacy has a strong influence on investment interests for the academics of the Bandung International Finance and Business Academy.
\end{abstract}

Keywords: Literacy, finance, decisions, investment, academicians

\section{Introduction}

Financial literacy is a set of skills and knowledge that enables individuals to make effective decisions about their investments to improve their finances (Mitchell \& Lusard, 2015). Financial literacy as an effort to increase public sensitivity to the financial services sector, which begins with knowing, then believing, to become skilled to be actively involved, in other words reaching a well literate community in the financial services sector; namely the banking sector, insurance, financing institutions, pension funds, capital markets, and pawnshops (Arya, 2018).

According to ASIC (2011) defines financial literacy as the ability to understand financial conditions and financial concepts and to transform that knowledge appropriately into behavior. Poterba et al. (2007) also define financial literacy as the ability to use knowledge and expertise to manage financial resources to achieve prosperity. According to Potrich et al. (2015) states that by definition literacy is defined as the ability to understand, so financial literacy is the ability to manage the funds owned to develop and live more prosperously in the future.

An important goal of the financial literacy program is to educate the Indonesian public so that they can manage their finances intelligently so that the low level of knowledge about the financial industry 
can be overcome and the public is not easily fooled into investment products that offer high returns in the short term without considering the risks. The need for public understanding of the products and services offered by financial service institutions, the national financial literacy strategy program has three main pillars. First, promoting education programs and national financial literacy campaigns. Second, in the form of strengthening financial literacy infrastructure. Third, talk about developing affordable financial products and services. The application of the three pillars is expected to realize Indonesian people who have a high level of financial literacy so that people can choose and utilize financial service products to improve welfare (Atkinson \& Messy, 2012).

This is the main goal of the National Financial Literacy Strategy, to realize Indonesian people who have a high level of financial literacy (well literate) so that people can choose and utilize financial products and services to improve welfare. Conversely, a low level of financial literacy results in a lack of utilization of facilities in the financial sector by the public. In addition, poor management of personal finances can result in financial difficulties such as misuse of credit cards and lack of financial planning. Financial difficulties can cause stress, low self-confidence, even for some families can lead to divorce. Financial literacy is vital for a prosperous and quality life. From these results a new problem arises, namely whether financial literacy affects individual investment decisions.

This paper intends to conduct research on the effect of financial literacy on investment interests among academicians. This study aims to determine the extent to which financial literacy affects individuals in investment decisions. The subjects in this study were lecturers, employees, and active students majoring in management and accounting International Finance and Business Academy in Bandung with the number of questionnaire respondents totaling 300 respondents.

\section{Literature Review}

\subsection{Financial Literacy}

"According to Morgan \& Trinh (2019) financial literacy is a set of skills and knowledge that enables an individual to make effective decisions with all their financial resources."

"Atkinson \& Messy (2012) explain that financial literacy helps individuals to avoid financial problems." Financial difficulties are not only a function of income alone (low income). Financial difficulties can also arise if there are mistakes in financial management (missmanagement) such as mistakes in the use of credit, and lack of financial planning. Financial limitations can cause stress, and low self-confidence. The existence of financial knowledge and financial literacy will help individuals in managing personal financial planning, so that individuals can maximize the time value of money and the benefits obtained by individuals will be even greater and will improve their standard of living.

"According to Mitchell \& Lusard (2015) financial literacy can be interpreted as financial knowledge to achieve prosperity." This can be interpreted that preparations need to be made to welcome globalization, more specifically globalization in the financial sector.

"According to ASIC (2011) means that financial literacy is the ability to understand financial conditions and financial concepts and to convert that knowledge precisely into behavior."

"Potrich et al. (2015) explain financial literacy is very important for several reasons. First, consumers who have financial literacy can go through difficult financial times because they may have accumulated savings, buy insurance and diversify their investments. Second, financial literacy also directly correlates with positive financial behavior such as timely bill payments, loan installments, savings before they run out and using credit cards wisely.

\subsection{General Personal Finance Knowledge}

"According to Soeryana et al. (2017), general personal finance knowledge is knowledge about personal finance in general. " Financial management is defined as the process of planning, analyzing, and controlling financial activities. The application form of financial management is personal financial 
management, including money management, spending and credit, as well as savings and investment.

\subsection{Savings and Borrowing}

\section{- Savings}

Collecting funds means collecting or seeking funds (money) from the wider community. The funds that have been collected are called bank deposits. These forms of savings include current accounts, savings and deposits (Sukono et al., 2018).

The purpose of saving in the form of demand deposits is the ease of withdrawal, especially for those in the business world. The purpose of saving money in savings is the ease of withdrawal as well as the expectation of getting greater interest from current accounts. And the purpose of saving money in the form of deposits is to expect greater interest (Poterba et al., 2007).

\section{- Borrowing}

One of the tasks of banks is to channel funds to the public in the form of loans or credit. Based on Banking Law No.10 of 1998, the term credit is "Provision of money or bills which can be equaled, based on a loan agreement between the bank and another party that requires the borrower to repay the debt after a certain period with interest. "

In general, the types of credit include:

- Investment credit, is credit given to entrepreneurs who make investments or investments.

- Working capital loans, are loans that are used as business capital. Usually these loans are short term, which is less than one year.

- Trade credit, is credit given to traders to expedite or develop their trading activities.

- Productive credit, is credit that can be in the form of investment, working capital or trade. In the sense that this credit is given to try again so that credit repayments are expected from the results of the business being financed.

- Consumptive credit, is credit used for personal needs such as consumption needs. For example, housing loans, vehicles, electronics, etc.

- Professional credit, is credit given to professionals, such as lecturers, doctors, or lawyers.

\subsection{Insurance}

Definition of insurance in Poterba et al. (2007) is a guarantee given by the guarantor (insurance company) to the insured (customer) for the risk of loss as specified in the agreement (policy) in the event of a fire, loss, damage, etc. or regarding the loss of life (death) or other accident, with the insured (customer) paying a premium equal to the policy agreement each month.

Other forms of insurance, among others:

1. Loss Insurance, is insurance that provides compensation to customers who have experienced material losses, losses incurred due to disasters or hazards, in the form of losses in the form of

- Loss of use-value,

- Deduction in value, or

- $\quad$ Loss of profits expected by the insured.

Insurance companies do not have to pay compensation to customers if during the term of the agreement the object of coverage does not experience a disaster or insured danger.

2. Life Insurance, is an agreement about payment of money from premiums related to life protection of customers, but not including accident insurance (which is included in loss insurance) based on (Poterba et al., 2007). In life insurance that contains deposits/investments, the guarantor will still return the amount of money promised to the insured under conditions,

- $\quad$ The insured dies within the validity period of the agreement,

- $\quad$ or upon the expiration of the agreement period.

3. Social Insurance, is insurance that provides guarantees to the community and is administered by the government. For example, traffic accident insurance (Jasa Raharja), TASPEN Insurance, ASKES, and others. Social insurance can be either as loss insurance or as life insurance. 


\subsection{Investment}

Investment is a commitment to several funds or other resources made at this time, intending to obtain several benefits in the future (Soeryana et al., 2017; Sukono et al., 2018). Those who make investments are called investors. Investors can be classified into two, namely individual investors (individual / retail investors) and institutional investors (institutional investors).

Individual investors consist of individuals who carry out investment activities, while institutional investors consist of insurance companies, fund storage institutions, pension fund institutions, and investment companies. Investors also learn how to manage investor welfare (monetary wealth). This monetary welfare can be assessed from the sum of current income and the present value of future income.

According to (Soeryana et al., 2017; Sukono et al., 2018). several reasons someone invests, including:

- To get a more decent life in the future.

- A wise person will think of improving his standard of living from time to time or at least try to maintain his current income level so as not to decrease in the future.

- Reducing inflationary pressures.

- By investing in the ownership of a company or other object, a person can avoid the risk of impairment of his wealth or property due to the influence of inflation.

- Encouragement to save taxes.

- There are policies in several countries that are encouraging the growth of investment in the community through the provision of taxation facilities to the public who invest in certain business fields.

Meanwhile, the basics that support investment decisions:

- Return, is the level of return on investment as a return on funds that have been invested by investors. While the return of investors' expectations from their investments is compensation for opportunity costs and the risk of decreasing purchasing power due to the influence of inflation. In the context of investment management, it is necessary to distinguish between expected returns and realized returns. Expected return is the level of return that is expected to be obtained by investors in the future, while the actual return is the return that has occurred calculated based on historical data.

- -Risk, is the possibility of actual return lower than the expected minimum return. In investing, investors expect high returns, but the amount of risk borne must also be taken into account. Generally, the greater the risk, the greater the expected return.

In investment decisions, there are five stages in decisions that go on and on until the best investment decisions are reached. The five stages of the decision include:

a. Determination of investment objectives.

The investment objectives of each investor are different, for example a pension fund that aims to obtain funds to pay for the pension fund of its customers in the future is likely to choose an investment in a mutual fund portfolio. Whereas for fund-holding institutions such as banks, aim to obtain a higher return and will invest in securities that are more easily traded or in credit dealers who are riskier but provide high return expectations.

b. Determination of investment policies.

This stage is the stage of determining policies to meet the stated investment objectives. Starting with determining the asset allocation decision (asset allocation decision). This decision concerns the distribution of funds held to various classes of assets available (stocks, bonds, property, etc.). Investors must also pay attention to restrictions that affect investment policies such as the number of funds owned, the portion of the distribution of these funds, as well as the tax burden and reporting that must be borne.

c. Selection of portfolio strategies. 
The portfolio strategy chosen must be consistent with the previous two stages. Two portfolio strategies can be chosen, namely active portfolio strategy and passive portfolio strategy. An active portfolio strategy includes the activities of using available information and forecasting techniques actively to find a better portfolio combination. Passive portfolio strategies include investment activities in portfolios that are in line with market index performance. This passive strategy assumes that all available information will be absorbed by the market and reflected on stock prices.

With an active strategy, investors try to identify stocks that are likely to be good in the future. In other words, investors try to find winners. Conversely with a passive strategy, investors can buy mutual funds (mutual funds). Simultaneously consider asset allocation and selection of securities.

d. Selection of assets.

This stage aims to find a combination of efficient portfolios, ie portfolios that offer the highest expected return with a certain level of risk, or conversely offer a certain expectation of returns with the lowest level of risk.

e. Measurement and evaluation of portfolio performance.

The final stage of the investment decision process, but not the last stage. Because investment decisions are continuous and continuous decision processes, meaning that if the measurement and evaluation stages of work have been passed but the results are not good, the investment decision process must start again from the first stage and so on until the most optimal investment decisions are reached.

The measurement and evaluation phase of this work includes measuring portfolio performance and comparing the measurement results with other portfolio performance through the benchmarking process. This benchmarking process is carried out on the market portfolio index, to find out how well the performance of the portfolio has been determined compared to the performance of other portfolios (market portfolios).

Factor theories that influence investment decisions, according to (Soeryana et al., 2017; Sukono et al., 2018). investment is a commitment to a number of funds or other resources made at this time. With the aim of obtaining a number of benefits in the future. In a sense, investors invest funds in forms such as stocks, land, buildings, with the aim of obtaining future profits.

\subsection{Hypothesis}

$H_{a, 1}$ : Financial literacy simultaneously influences investment interests in the Indonesian Academy of Finance and International Business, Bandung.

$H_{a, 2}$ : Financial literacy partially influences investment interest in the Indonesian Academy of Finance and International Business, Bandung.

\section{Research Method}

\subsection{Research Approac}

In this study, the authors used a quantitative descriptive approach. Descriptive research according to Sugiyono. (2010) is a research method carried out to find out the value of independent variables or more (independent) without making comparisons or combining variables. While the quantitative method is said because the research data in the form of numbers and analyzed using statistics.

\subsection{Research Objects and Subjects}

According to Sugiyono. (2010), the object of research is a scientific goal to get data with specific goals and uses about something objective, valid, and reliable about a thing (certain variables). The object of this research is Financial Literacy which consists of four aspects, namely General Personal Finance Knowledge, Savings and Borrowing, Insurance, and Investments. 
Research subjects according to Sugiyono. (2010) are informants, which means people in the research setting are used to provide information about the situation and conditions of the research setting. The subjects of this study were lecturers, employees, and students at the Indonesian Academy of Finance and International Business, Bandung.

\subsection{Sampling Techniques}

Sugiyono (2010) states that population is defined as a generalization area consisting of objects / subjects that have certain quantities and characteristics determined by researchers to be studied and then drawn conclusions. Populations of this study are lecturers, employees, and students at the Indonesian Academy of Finance and Business International (AKBII), Bandung. which numbered 500 people. The sample is part of the number and characteristics possessed by the population. The sample was obtained by purposive sampling, which is the technique of determining the sample with certain considerations. (Sugiyono, 2010)

Criteria from the sample include;

- Lecturers, employees, and students at the Indonesian Academy of Finance and International Business (AKBII), Bandung.

- For students, working as employees or entrepreneurs, or not yet working.

As for sample calculation, the Slovin sample calculation formula is used, with the following formula.

$$
n=\frac{N}{1+N(e)^{2}}
$$

Where $n$ is the number of samples; $N$ is the population number; $e$ is the error rate $(5 \%)$

$$
n=\frac{600}{1+600(0.05)^{2}}=240
$$

So from the results of calculations using the formula above, obtained the number of samples from the population to be studied as many as 270 respondents.

\subsection{Data Types}

The data used in this study are primary data, primary data are data sources that directly provide data to data collectors (Sugiyono, 2010). The reason for using primary data as research material, because primary data produces information that is more accurate and relevant to the research being carried out.

\subsection{Teknik Pengumpulan Data}

The data source comes from a written survey in the form of a questionnaire that will be conducted by the writer to a sample of the population, namely lecturers, employees, and students at the Indonesian Academy of Finance and International Business, Bandung.

\subsection{Operational Definitions}

Measurement of the level of financial literacy, can use the following measurement scales:

1. The level of financial literacy is high, if the true score is more than $80 \%$.

2. Medium financial literacy level, if the score is right between $60 \%$ to $80 \%$.

3. The level of financial literacy is low, if the true score is less than $60 \%$.

The percentage of the level of financial literacy from this scoring technique is obtained from the results of respondents' answers on the questionnaire sheets that have been distributed by the author.

Multiple linear regression analysis is used to measure the effect of more than one independent variable on the dependent variable (Sugiyono, 2010). The general form of multiple linear regression equations is:

$$
\begin{array}{ll}
Y & =\text { Infestation decision; } \\
a & =\text { A constant }
\end{array}
$$




$$
\begin{array}{ll}
b_{1}, b_{2}, b_{3}, b_{4} & =\text { Coefficient; } \\
X_{1} & =\text { General Personal Finance Knowledge } \\
X_{2} & =\text { Savings and Borrowing } \\
X_{3} & =\text { Insurance } \\
X_{4} & =\text { Investments } \\
e & =\text { Error rate }
\end{array}
$$

\subsection{Data Analysis Techniques}

The data analysis technique used in this study is multiple linear regression analysis. Multiple linear regression is a linear relationship between two or more independent variables with the dependent variable. This analysis is used to determine the relationship between the independent variable with the dependent variable whether the variable is positively or negatively related and to predict the value of the independent variable.

\section{Results and Discussion}

\subsection{Multiple Linear Regression Analysis}

Table 1. Summary Model

Summary Model ${ }^{\mathrm{b}}$

\begin{tabular}{|r|r|r|r|r|}
\hline$R$ & $R$ Square & $\begin{array}{r}\text { Adjusted R } \\
\text { Square }\end{array}$ & $\begin{array}{r}\text { Std. Error of the } \\
\text { Estimate }\end{array}$ & $\begin{array}{r}\text { Durbin- } \\
\text { Watson }\end{array}$ \\
\hline .589 & .353 & .349 & 4.563 & 1.975 \\
\hline
\end{tabular}

a. Predictors: (Constant), TOTAL_X4, TOTAL_X3, TOTAL_X1, TOTAL_X2

b. Dependent Variable:TOTAL_Y

Source: Data Processing Results, 2019

From Table 1, the regression equation can be drawn as follows:

$$
Y=14.343+0.0479 x_{1}+0.2102 x_{2}+0.0638 x_{3}+0.2819 x_{4}+\varepsilon
$$

It can be concluded,

a. A constant value of 15,344 states that if there is no General Knowledge variable in Personal Finance, Deposits and Loans, Insurance, and Investment, the investment decision will be positive at 14.344 .

b. The multiple regression coefficient value of the General Knowledge Personal Finance variable $\left(\mathrm{X}_{1}\right)$ is 0.0479 , which means that for every increase in general personal finance knowledge by $1 \%$, the investment decision will increase by 0.0479 .

c. The multiple regression coefficient value of the Savings and Loans variable $\left(\mathrm{X}_{2}\right)$ is 0.2102 , which means that for every $1 \%$ increase in knowledge about deposits and loans, the investment decision will increase by 0.2102 .

d. The multiple regression coefficient value of the Insurance variable $\left(\mathrm{X}_{3}\right)$ is 0.0638 , which means that for every $1 \%$ increase in insurance knowledge, the investment decision will increase by 0.0638 .

e. The value of the multiple regression coefficient of the Investment variable $\left(\mathrm{X}_{4}\right)$ is 0.2819 , which means that every $1 \%$ increase in knowledge about investment, the investment decision will increase by 0.2819 . 


\subsection{Classical Assumption Test}

\subsubsection{Normality Test}

From the Kolmogorov-Sminorv Normality Test results indicate that the Asymp value. Sig. (2tailed) of 0.778 which is greater than the significance value of 0.05 . So it can be concluded that the overall data are normally distributed and the regression model is appropriate to be used to determine whether there is an influence of variable $X$ (general knowledge of personal finance, savings and loans, investment, and insurance) on the variable $\mathrm{Y}$ (investment decisions of lecturers, employees, and students).

Table 2. Kolmogorov-Sminorv Normality Test Results One-Sample Kolmogorov-Smirnov Test

\begin{tabular}{|c|c|c|}
\hline & & $\begin{array}{l}\text { Unstandardized } \\
\text { Residual }\end{array}$ \\
\hline \multicolumn{2}{|l|}{$\mathrm{N}$} & 231 \\
\hline \multirow{3}{*}{ Normal Parameters ${ }^{\mathrm{a}}$} & Mean & .0000000 \\
\hline & Std. & 4.51301094 \\
\hline & Deviation & \\
\hline \multirow{3}{*}{$\begin{array}{l}\text { Most Extreme } \\
\text { Differences }\end{array}$} & Absolute & .045 \\
\hline & Positive & .045 \\
\hline & Negative & -.035 \\
\hline \multirow{2}{*}{\multicolumn{2}{|c|}{$\begin{array}{l}\text { Kolmogorov-Smirnov Z } \\
\text { Asvmn Sig (2-tailed) }\end{array}$}} & .669 \\
\hline & & .788 \\
\hline
\end{tabular}

Source: Data Processing Results, 2019

\subsubsection{Uji Autokorelasi}

Table 3. Autocorrelation Test Results Model Summary

\begin{tabular}{|c|c|c|c|c|}
\hline $\mathrm{R}$ & R Square & $\begin{array}{c}\text { Adjusted R } \\
\text { Square }\end{array}$ & $\begin{array}{c}\text { Std. Error } \\
\text { of the } \\
\text { Estimate }\end{array}$ & $\begin{array}{c}\text { Durbin- } \\
\text { Watson }\end{array}$ \\
\hline $.589^{\mathrm{a}}$ & .353 & .349 & 4.563 & 1.975 \\
\hline
\end{tabular}

a. Predictors: (Constant), TOTAL_X4, TOTAL_X3, TOTAL_X1, TOTAL_X2

b. Dependent Variable:TOTAL_Y

Source: Data Processing Results, 2019

From the table above it is obtained that the DW value is 1.970 . The value of $d L=1.74873$ and $d U=1.81945$ is obtained from the Watson Durbin Table with a value of $n=231$, the number of variables $k=5$, and a significant 0.05 .

\begin{tabular}{|c|c|c|c|c|}
\hline $\mathrm{DW}$ & $\mathrm{dL}$ & $\mathrm{dU}$ & $4-\mathrm{dL}$ & $4-\mathrm{dU}$ \\
\hline 1.975 & 1.74872 & 1.81946 & 2.25137 & 2.18155 \\
\hline
\end{tabular}

On the basis of decision making:

$H_{0} \quad: \mathrm{dU}<\mathrm{DW}<4-\mathrm{dU}$, then there is no autocorrelation. 
$H_{1} \quad:$ DW $<\mathrm{dU} 4-\mathrm{dU}$ or $4-\mathrm{dU}<\mathrm{DW}$, then autocorrelation occurs.

Based on the table above it can be concluded that $\mathrm{H}_{0}$ is accepted, with $d U<D W<4-d U=$ $(1.81945<1.970<2.18055)$ which means that there is no autocorrelation.

The independent variable is general knowledge of personal finance, savings and loans, insurance and investment which are the four aspects of financial literacy that affect the dependent variable, namely the investment decisions of lecturers, employees, and students at the Indonesian International Finance and Business Academy, Bandung.

\subsubsection{Heteroskedaticity Test}

From the results of the heteroscedaticity test using the glacier test, it can be seen that the significant value of the general knowledge variable of personal finance $\left(\mathrm{X}_{1}\right)$ is 0.150 . Savings and loan variable $\left(\mathrm{X}_{2}\right)$ of 0.428 . Insurance variable $\left(\mathrm{X}_{3}\right)$ of 0.371 . The three variables above are significantly greater than 0.05 , which means that there is no heteroscedaticity in these variables.

However, the investment variable $\left(\mathrm{X}_{4}\right)$ has a significant value of 0.002 lower than 0.05 , indicating that heteroscedaticity occurs in that variable. Heteroscedaticity is caused by outliers, in this study, because the average respondent gives the same answer to one question item.

Table 4. Glejser Test Results

Coefficients $^{\text {a }}$

\begin{tabular}{|c|c|c|c|c|c|}
\hline \multirow[b]{2}{*}{ Model } & \multicolumn{2}{|c|}{$\begin{array}{l}\text { Unstandardized } \\
\text { Coefficients }\end{array}$} & \multirow{2}{*}{\begin{tabular}{|c|}
$\begin{array}{c}\text { Standardized } \\
\text { Coefficients }\end{array}$ \\
Beta \\
\end{tabular}} & \multirow[b]{2}{*}{$\mathrm{t}$} & \multirow[b]{2}{*}{ Sig. } \\
\hline & B & $\begin{array}{l}\text { Std. } \\
\text { Error }\end{array}$ & & & \\
\hline 1 (Constant) & .723 & 2.261 & & .320 & .759 \\
\hline TOTAL_X1 & -.034 & .023 & -.111 & -1.443 & .152 \\
\hline TOTAL_X2 & .030 & .037 & .071 & .793 & .438 \\
\hline TOTAL_X3 & -.026 & .029 & -.076 & -.896 & .372 \\
\hline TOTAL_X4 & .133 & .043 & .263 & 3.070 & .003 \\
\hline
\end{tabular}

a. Dependent Variable: ABS_RES

Source: Data Processing Results, 2019

\subsubsection{Multicollinearity Test}

Table 5. Multicollinearity Test Results

Coefficients $^{\mathrm{a}}$

\begin{tabular}{|c|c|c|c|c|c|c|c|}
\hline \multirow{2}{*}{ Model } & \multicolumn{2}{|c|}{$\begin{array}{c}\text { Unstandardized } \\
\text { Coefficients }\end{array}$} & $\begin{array}{c}\text { Standardized } \\
\text { Coefficients }\end{array}$ & \multirow{2}{*}{$\mathrm{T}$} & \multicolumn{2}{|c|}{$\begin{array}{c}\text { Collinearity } \\
\text { Statistics }\end{array}$} \\
\cline { 2 - 4 } & $\mathrm{B}$ & $\begin{array}{c}\text { Std. } \\
\text { Error }\end{array}$ & Beta & & Tolerance & VIF \\
\hline 1 (Constant) & 15.344 & 3.690 & & 4.158 & .000 & & \\
TOTAL_X1 & .048 & .038 & .080 & 1.259 & .209 & .705 & 1.429 \\
TOTAL_X2 & .210 & .061 & .254 & 3.430 & .001 & .524 & 1.912 \\
TOTAL_X3 & .064 & .048 & .094 & 1.334 & .184 & .576 & 1.747 \\
TOTAL_X4 & .282 & .071 & .285 & 3.991 & .000 & .564 & 1.775 \\
\hline
\end{tabular}

a. Dependent Variable: TOTAL_Y

Based on Table 5, the tolerance value $(\alpha)$ is calculated for the General Knowledge Personal Finance $\left(\mathrm{X}_{1}\right)$ variable of 0.705 ; Savings and Loans variable $\left(\mathrm{X}_{2}\right)$ of 0.524 ; Insurance variable $\left(\mathrm{X}_{3}\right)$ of 0.576 ; and 
Investment variable $\left(\mathrm{X}_{4}\right)$ of 0.564 .

The tolerance value $(\alpha)$ of the four independent variables is greater than what has been set, which is 0.1. Then the calculated VIF value for the General Knowledge Personal Finance variable is 1.419; Savings and Loans variables 1,910; Insurance variable of 1.737; and Investment variable 1.774. The VIF value of the four independent variables is smaller than the VIF value, which is 10 .

So it can be concluded that there are no symptoms of multicollinearity in this study, and the four independent variables can be used to predict investment decisions of lecturers, employees, and students at the Indonesian Academy of Finance and Business International, Bandung. during the observation period.

\subsection{Hypothesis Testing}

\subsubsection{Test $F$}

The hypothesis used in this $\mathrm{F}$ test is

$H_{0,1}$ : Financial literacy does not simultaneously affect investment decisions at the Indonesian

Academy of Finance and International Business (AKBII), Bandung.

$H_{a, 1}$ : Financial literacy simultaneously influences investment decisions at the Indonesian Academy of

Finance and International Business (AKBII), Bandung.

Significant level of value is $0.05(5 \%)$ on the basis of decision making as follows:

1. $F_{\text {hitung }} \leq F_{\text {tabel }}$, then $H_{0.1}$ is accepted and $H_{a, 1}$ is rejected.

2. $F_{\text {hitung }}>F_{\text {tabel }}$, then $H_{0.1}$ is rejected and $H_{a, 1}$ is accepted.

The following table shows the results of processing the $\mathrm{F}$ test data.

Table 6. Test Results F

ANOVA $^{\mathrm{b}}$

\begin{tabular}{|c|l|l|l|c|c|}
\hline Model & \multicolumn{1}{|c|}{$\begin{array}{c}\text { Sum of } \\
\text { Squares }\end{array}$} & \multicolumn{1}{c|}{ df } & Mean Square & F & Sig. \\
\hline 1 Regression & 2526.100 & 4 & 631.525 & 30.468 & $.000^{\mathrm{a}}$ \\
Residual & 4684.472 & 226 & 20.728 & & \\
Total & 7210.571 & 230 & & & \\
\hline
\end{tabular}

a. Predictors: (Constant), TOTAL_X4, TOTAL_X3, TOTAL_X1,TOTAL_X2

b. Dependent Variable:TOTAL_Y

From the calculation results in table 4.19 , the $F_{\text {count }}$ was 30.468 with a significant value of 0.000 . The value of $\mathrm{F}_{\text {table }}$ with $d f 1=k-1(d f 1=5-1 ; d f 1=4)$ and $d f 2=n-k(d f 2=231-5 ; d f 2=226)$ is worth 2.411590. Thus obtained (30.468) is greater than $F_{\text {table }}$ (2.411590), which means that $H_{0.1}$ is rejected and $H_{a .1}$ is accepted. Then the significant value of 0.000 is smaller than the significance level of 0.05 . This means that general knowledge of personal finance, savings and loans, insurance, and investment which are the four aspects of financial literacy simultaneously have a significant influence on investment decisions at the Indonesian Academy of Finance and International Business (AKBII), Bandung..

\subsubsection{T-test}

The hypothesis used is as follows:

$H_{0.2}$ : General Knowledge of Personal Finance, Deposits and Loans, Insurance and Investment partially does not affect investment decisions at the Indonesian Academy of Finance and International Business (AKBII), Bandung. 
$H_{a .2}$ : General Knowledge of Personal Finance, Deposits and Loans, Insurance, and Investment partially influences investment decisions at the Indonesian Academy of Finance and International Business (AKBII), Bandung.

Significant level of value is $0.05(5 \%)$ on the basis of decision making as follows:

1. $T_{\text {hitung }} \leq T_{\text {tabel }}$, then $H_{0.2}$ is accepted and $H_{a, 2}$ ditolak.

2. $T_{\text {hitung }}>T_{\text {tabel }}$, then $H_{0.2}$ is rejectedand $H_{a, 2}$ is accepted.

The following table shows the results of t-test data processing.

Table 7. T-Test Results

Coefficients $^{\text {a }}$

\begin{tabular}{|c|c|c|c|c|c|}
\hline \multirow[b]{2}{*}{ Model } & \multicolumn{2}{|c|}{$\begin{array}{l}\text { Unstandardized } \\
\text { Coefficients }\end{array}$} & \multirow{2}{*}{\begin{tabular}{|c|}
$\begin{array}{c}\text { Standardized } \\
\text { Coefficients }\end{array}$ \\
Beta
\end{tabular}} & \multirow[b]{2}{*}{$\mathrm{t}$} & \multirow[b]{2}{*}{ Sig. } \\
\hline & B & $\begin{array}{l}\text { Std. } \\
\text { Error }\end{array}$ & & & \\
\hline 1 (Constant) & 15.344 & 3.690 & & 4.158 & .000 \\
\hline TOTAL_X1 & .048 & .038 & .080 & 1.259 & .208 \\
\hline TOTAL_X2 & .210 & .061 & .254 & 3.430 & .002 \\
\hline TOTAL_X3 & .064 & .048 & .094 & 1.334 & .185 \\
\hline TOTAL_X4 & .282 & .071 & .285 & 3.991 & .000 \\
\hline
\end{tabular}

a. Dependent Variable: TOTAL_Y

Based on the table above it can be seen that the results of the t-test for the General Knowledge Personal Finance $\left(\mathrm{X}_{1}\right)$ variable obtained a Tcount of 1.259 with a significant value of 0.209 . The value of $T_{\text {table }}$ with $d f=n-k-1(d f=231-5-1=225)$ is equal to 1.651654 . Thus it can be concluded that $T_{\text {count }}(1.442)$ is smaller than $T_{\text {table }}(1.651654)$, meaning that General Knowledge of Personal Finance partially does not affect investment decisions. And a significant value of $0.151>0.05$ indicates that the variable $\mathrm{X}_{1}$ partially did not have a significant effect.

T-test results for the Savings and Loans variable $\left(\mathrm{X}_{2}\right)$ obtained a $T_{\text {count }}$ of 3.430 with a significant value of 0.001 . The value of $\mathrm{T}$-count variable $\mathrm{X}_{2}(3.430)$ is greater than $T_{\text {table }}(1.651654)$ and the significant value of 0.001 is smaller than 0.05 . So it can be concluded that the Savings and Loans variables partially have a significant influence on investment decisions.

T-test results for the Insurance variable $\left(\mathrm{X}_{3}\right)$ obtained a $T_{\text {count }}$ of 1.334 with a significant value of 0.184 . The value of $T_{\text {count }}$ variable $\mathrm{X}_{3}(1.334)$ is smaller than $T_{\text {table }}(1.651654)$ and the significant value of 0.184 is greater than 0.05 . So it can be concluded that the Insurance variable partially does not have a significant influence on investment decisions.

T-test results for the Investment variable $\left(\mathrm{X}_{4}\right)$ obtained a $T_{\text {count }}$ of 3.991 with a significant value of 0.000 . The value of $T_{\text {count }}$ variable $\mathrm{X}_{4}(3,991)$ is greater than $T_{\text {table }}(1.651654)$ and a significant value of 0.000 is smaller than 0.05 . So it can be concluded that the investment variable partially has a significant influence on investment decisions.

\section{Conclussion}

In this paper, a study entitled Analysis of the Effect of Financial Literacy on Investment Decisions at the Indonesian Academy of Finance and International Business (AKBII), Bandung. Based on the results of the discussion it can be concluded that aspects of financial literacy including general knowledge of personal finance, savings and loans, insurance, and investment simultaneously (overall) have a significant influence on investment decisions of lecturers, employees, and students at Indonesian 
Academy of Finance and International Business (AKBII), Bandung. Can be seen from the results of the F test with a value of $F_{\text {count }}(29.889)$ greater than $F_{\text {table }}(2.423286)$ and a significant value of 0.000 is smaller than the significant value of 0.05 . However, only partial aspects of savings and loans and investment alone significantly influence investment decisions of lecturers, employees, and students at the Indonesian Academy of Finance and International Business (AKBII), Bandung. Because aspects of savings and loans and investments are directly related to how individuals manage assets or cash, make loans and then determine the appropriate form of investment to guarantee finances in the short and long term.

\section{References}

ASIC (2011). National financial literacy strategy. Australian Securities \& Investment Commission Report No. 29. http://www.financialliteracy.gov.au/media/218312/ nationalfinancial-literacy-strategy.pdf, on 25 January, 2020.

Arya, P. (2018). Financial Literacy and Financial Education in India: An Assessment. International Research Journal of Commerce Arts and Science, Volume 9, Issue 3, 2018; pp. 72-80.

Atkinson, A. \& Messy, F. (2012), "Measuring Financial Literacy: Results of the OECD / International Network on Financial Education (INFE) Pilot Study", OECD Working Papers on Finance, Insurance and Private Pensions, No. 15, OECD Publishing.http://www.oecd.org/

Mitchell, O.S. \& Lusard, A. (2015). Financial Literacy and Economic Outcomes:Evidence and Policy Implications. Working Paper. The Wharton School, University of Pennsylvania; pp. 1-17.

Morgan, P.J. \& Trinh, L.Q. (2019). Determinants and Impacts of Financial Literacy in Cambodia and Viet Nam. Journal of Risk Financial Manag,. 2019, 12, 19; pp. 1-24.

Potrich, A.C.G., Vieira, K.M., \& Kirch, C. (2015). Determinants of Financial Literacy: Analysis of the Influence of Socioeconomic and Demographic Variables. R. Cont. Fin. - USP, São Paulo, v. 26, n. 69, p. 362-377, set./out./nov./dez. 2015; pp. 362-372.

Poterba, J., Venti, S., \& Wise, D. A. (2007). The changing landscape of pensions in the United States. Technical Report, National Bureau of Economic Research. Tankha.A. (2011). Financial literacy: concept and its importance in India. http://w.sadhan.net/Adls/Microfinance/ PerspectiveMicrofinance/SelfhelpGroupsas Financial.pdf

Soeryana, E., Halim, N.B.A., Sukono, Rusyaman, E., \& Supian, S. 2017. Mean-Variance Portfolio Optimization by Using Time Series Approaches Based on Logarithmic Utility Function. IOP Conf. Series: Materials Science and Engineering 166 (2017) 012003 doi:10.1088/1757-899X/166/1/012003.

Sugiyono. (2010). Metode Penelitian Pendidikan Pendekatan Kuantitatif, Kualitatif, Dan R\&D. Bandung: Alfabeta.

Sukono, Susanti, D., Najmia, M., Lesmana, E., Napitupulu, H., Putra, A.S., \& Supian, S. 2018. Analysis of Stock Investment Selection Based on CAPM Using Covariance and Genetic Algorithm Approach. IOP Conf. Series: Materials Science and Engineering, 332 (2018) 012046 doi:10.1088/1757-899X/332/1/012046. 